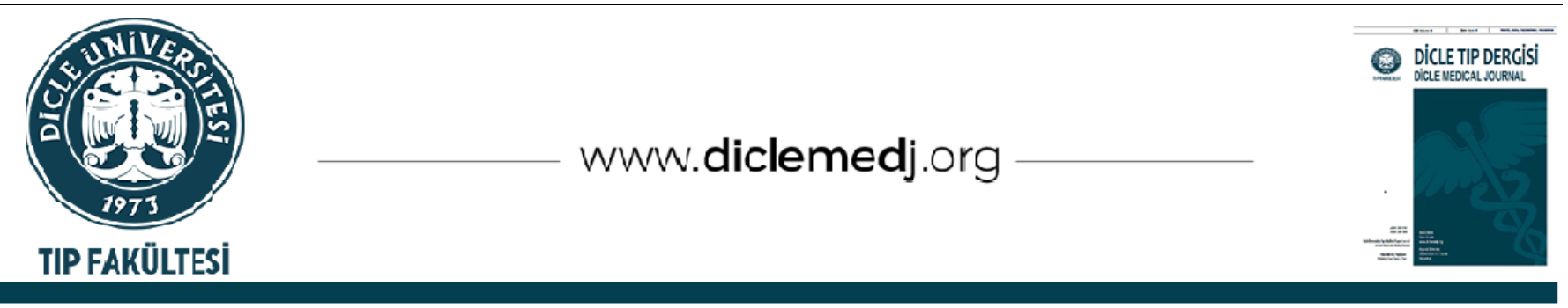

Original Article / Özgün Araştırma

\title{
Comparison of Therapeutic Plasma Exchange and Double Filtration Plasmapheresis: Five Year Experience of Nephrology Unit
}

\author{
Sibel Gokcay Bek ${ }^{1}$, Serkan Bakırdöğen ${ }^{2}{ }_{2}$, Necmi Eren ${ }^{1}{ }_{1}$, Yusuf Hanazay ${ }^{D_{3}}{ }_{\text {, }}$ \\ Betul Kalender Gonullu ${ }^{2}{ }_{2}$ \\ 1 Nephrology, Kocaeli University Hospital, Kocaeli, Turkey \\ 2 Nephrology, 18 Mart University Hospital, Çanakkale, Turkey \\ 3 Internal Medicine, Kocaeli University Hospital, Kocaeli, Turkey
}

Received: 10.05.2021; Revised: 22.08.2021; Accepted: 23.08.2021

\begin{abstract}
Objective: The aim of the study was to evaluate the outcomes and characteristics of therapeutic plasma exchange (TPE) and double filtration plasmapheresis (DFPP) in one center.

Method: The data of cases treated with therapeutic plasmapheresis at the university hospital between 2007 and 2012 were retrospectively analyzed. 445 TPE and 391 DFPP sessions were done totally.

Results: In the 5.5 years, in 116 cases 445 TPE and 391 DFPP sessions were done. The mean age was $46.61 \pm 16.83$ years. There were 49 female and 67 male patients. Guillain-Barre syndrome ( $8.6 \%$ ) was the commonly encountered indication for neurological diseases, glomerulonephritis ( $25 \%$ ) was the leading indication for the renal-related diseases. Skin involvement due to diabetes mellitus (13.8\%) and Pemphigus Vulgaris (5.2\%) were the dermatological diseases. Complication rates were similar between DFPP and TPE sessions $(\mathrm{p}=0.411)$.

Conclusion: TPE and DFPP are safe and vital membrane separation techniques used as a treatment for a wide spectrum of diseases. These treatments can be safely done in hemodialysis units intensive care units and DFPP should be considered for the therapy refractory neurological diseases.
\end{abstract}

Keywords: Double filtration plasmapheresis - Theurapetic plasma exchange

DOI: 10.5798/dicletip.988064

Correspondence / Yazışma Adresi: Sibel Gokcay Bek, Nephrology Department Kocaeli University Hospital, Kocaeli, Turkey e-mail: beksibel@gmail.com, sibel.bek@kou.edu.tr 


\section{Terapötik Plazmaferez ve Çift Filtreli Plazmaferez Tedavisinin Karşılaştırılması- Beş Yıllık Nefroloji Merkez Deneyimi}

Öz

Giriş: Bu çalışmanın amacl, tek merkezde yapılan terapötik plazma değişimi ve çift filtreli plazmaferez tedavisinin sonuçlarının ve özelliklerinin değerlendirilmesidir.

Yöntemler: 2007-2012 yılları arasında üniversite hastanesinde terapötik plazmaferez ile tedavi edilen olguların verileri geriye dönük olarak incelendi. 445 TPE ve 391 DFPP seansı yapıldı

Bulgular: 5.5 yılda 116 vakada 445 seans TPE ve 391 seans DFPP yapıldı. Ortalama yaş 46.61ะ16.83yıldı. 49 kadın ve 67 erkek hasta vardı. Guillain-Barre sendromu (\%8.6) nörolojik hastalıkların en sık rastlanan nedeni iken, böbrekle ilgili hastalıklarda en sık neden glomerülonefritlerdi (\%26.1). Dermatolojik hastalıkların nedenleri Diyabetes Mellitus (\%13.8) ve Pemfigus Vulgarisdi (\%5,2). DFPP ve TPE komplikasyon oranları arasında fark yoktu ( $\mathrm{p}=0.411)$.

Sonuç: TPE ve DFPP, çok çeşitli hastalıkların tedavisi olarak kullanılan güvenli ve hayati önemi olan tedavi yöntemleridir. $\mathrm{Bu}$ tedaviler hemodiyaliz üniteleri yoğun bakım ünitelerinde güvenle yapılabilir ve tedaviye dirençli nörolojik hastalıklarda ilk seçenek olarak DFPP kullanılabilinir.

Anahtar kelimeler: Çift filtrasyon plazmaferez, Plazmaferez

\section{INTRODUCTION}

Therapeutic plasma exchange (TPE) is a kind of blood purification technique to remove the pathogens via a plasma filter, and then giving the components of plasma back to the blood circulation ${ }^{1}$. Double filtration plasmapheresis (DFPP) is another technique in the separation of plasma from the blood via a separator and a plasma fractionator was used for the removal of components. Then plasma is combined with cellular blood components and given back to patients without the need for replacement colloid ${ }^{2}$. This therapy is used for the treatment of diseases and the primary and adjunctive therapy indications are based on controlled trials with minimal risk and maximum benefit ${ }^{3}$.

The indications and efficacy of, TPE in each condition are based on controlled trials and clinical experiences. In most of the trials of TPE, centrifugal machines were used but membrane filtration is also found to be efficient in most situations ${ }^{1}$. In each standard TPE procedure, plasma volume is preferred to be 1-1.5 times the total plasma. The frequency and the total number of TPE treatments are set by the features of the disease being treated.
In most of the diseases, autoantibody is targeted for removal ${ }^{2}$. In other circumstances, it can be an antibody, a cryoglobulinic protein, an immunoglobulin or a non-immunoglobulin protein $^{2}$. Removal of the pathogenic materials is done by removal of the collected material and instead of removed material replacement solution which can be albumin or a combination of albumin, saline,and transfused plasma are given. To avoid the need for replacement colloids, the devices purifying the plasma online are favored like 'double filtration' plasmapheresis that discards the proteins bigger than $100 \mathrm{kDa}$. Though this treatment modality is not suitable for the management of some primer glomerular diseases, light-chain glomerulopathy, and myeloma cast nephropathy ${ }^{1}$.

According to the registries, the most common indications were neurologic diseases (32.5\%). Renal indications are $2.4-7 \%$ of TPE indications which are rapidly progressive glomerulonephritis, TTP, kidney transplant rejection, and cast nephropathy ${ }^{4}$. TPE is found to be very efficient to decrease disease progression in cases with rapidly progressive glomerulonephritis and vasculitis 4 . TPE is also 
efficient for the cases with myeloma cast nephropathy 5 and most of the acute kidney injuries caused by thrombotic microangiopathy with lupus nephritis ${ }^{6,7}$.

This study aims to evaluate the indications, and the outcomes of the cases treated with the therapeutic plasmapheresis.

\section{METHODS}

The data of the cases who were treated with the therapeutic plasmapheresis at the University Hospital between 2007 and 2012 were retrospectively evaluated. The data were obtained from the database which is the collection of the University Hospital. This study was accepted by University Ethical Committee with the document number KOU-GOKAEK-2019/328.

445 TPE and 391 DFPP sessions were done totally. All patients $\geq 18$ years old with renal and neurological indications for plasmapheresis were included. Lipid apheresis and plasmapheresis for end-stage liver failure were excluded. The epidemiologic and laboratory findings on admission to the hospital were obtained. The treatment details and modalities were also evaluated. The primary outcome was all-cause mortality.

\section{Procedure}

The Fresenius 4008S machine (Fresenius Medical Care Deutschland GmbH, Hamburg, Germany) was used for TPE. The volume of replacement was set as 1.5 times of the estimated plasma, calculated with the formula of $(0.065 \mathrm{x}$ weight in kg) x (1-hematocrit). The replacement was done with plasma for TTP and hemolytic uremic syndrome (HUS) and 5\% albumin for others. A 10 $\%$ calcium gluconate intravenous infusion was done during the TPE sessions.

The patients in the DFPP group (47.4\%) were treated with the Plasauto EZ Asahi machine (Asahi Kasei Kuraray Medical Co, Tokyo, Japan) with the double filtration. A central dual-lumen venous catheter was used as access and all were given concomitant therapy, most of the time with immunosuppressive agents.
The indications of TPE and DFPP were mostly done in parallel to the guideline of the American Society for Apheresis (ASFA) 3. A single-use plasmapheresis filter was used in each session. The result after treatment was defined as complete-response or non-response. Complete response was defined with the total disappearance of all clinical and laboratory findings following planned sessions. No response to treatment was defined when the patients had no improvement after at least five treatment sessions in clinical and laboratory findings or when the patients had prompt recurrence after cessation of treatment. Partial remission includes clinical state not covering the complete and nonresponse criteria.

\section{Statistical Analysis}

Continuous variables were given as means $\pm S D$, and categorical ones were given as proportions. Continuous variables were evaluated with a t-test. Categorical variables were evaluated with the chisquare test. The p-values less than 0.05 were considered significant. Statistical analyses were performed using SPSS version 13.0 for Windows software (International Business Machines, Armonk, NY).

\section{RESULTS}

In the period of 5.5 years, of 116 patients were treated with (n:61, 52.6\%) 445 sessions of TPE and (n:55 , 47.4\%) 391sessions of DFPP. The mean age was $46.61 \pm 16.83$ years. There were 49 women and 67 men. 125 aXaICU/kg low molecular weight heparin was preferred.

Glomerulonephritis (n: 29, 25\%) and HUS (n:12, $10.3 \%$ ) were the most common renal indications for TPE group. Guillain- Barré syndrome (n:10, $8.6 \%$ ) was the leading neurological indication in DFPP group. Dermatological indications were Diabetes Mellitus related skin conditions (n:16 ,13.8\%), Pemphigus Vulgaris-(n:6, 5.2\%), drug eruptions (n: $2,1.7 \%$ ) in DFPP group.

$44.8 \%$ of the patients were given immunosuppressive treatment and $6.9 \%$ of patients were treated with intravenous 
immunoglobulin (IVIG) simultaneously. Twelve of the neurology patients and two TTP patients were admitted from the intensive care unit and all of the procedures were done in the hemodialysis unit instead of intensive care unit.

The mean of the hematocrit was $31.6 \% \pm 7.29$, the mean of the albumin was $3.14 \pm 0.73 \mathrm{gr} / \mathrm{dl}$, and the mean of the serum creatinine was $2.77 \pm 2.4$ $\mathrm{mg} / \mathrm{dl}$. Creatinine levels decreased with TPE sessions in chronic kidney disease patients [kidney transplant patients $(\mathrm{p}<0.001)$, glomerulonephritis ( $\mathrm{p}<0.005)$, HUS $(\mathrm{p}=0.024)$, ANCA- associated vasculitis $(\mathrm{p}=0.03)]$ and no significant change was found in albumin and $\mathrm{Ca}$ levels before and after sessions. A decrease in albumin levels after sessions were higher in the TPE group in comparison with the DFPP group $(p<0.001)$. There was a decrease in lactate dehydrogenase levels $(p=0.035)$ and an increase in platelet levels $(p=0.012)$ after TPE sessions with HUS patients. Laboratory changes after TPE and DFPP sessions were given in Tables 1 and 2 .

Table I: Laboratory changes after TPE sessions

\begin{tabular}{|c|c|c|c|c|}
\hline & n & $\begin{array}{l}\text { Before TPE } \\
\text { (Mean } \pm S D)\end{array}$ & $\begin{array}{c}\text { After TPE } \\
\text { (Mean } \pm \text { SD) }\end{array}$ & $\mathbf{p}$ \\
\hline $\begin{array}{l}\text { Hemoglobin } \\
\text { (g/dl) }\end{array}$ & 61 & $10.6 \pm 2.42$ & $10.5 \pm 2.18$ & 0.22 \\
\hline $\begin{array}{l}\text { Hematocrit } \\
\text { (\%) }\end{array}$ & 61 & $31.6 \% \pm 7.29$ & $31.09 \pm 6.64$ & 0.34 \\
\hline $\begin{array}{l}\text { Platelets } \\
\left(10^{9} / \mathrm{L}\right)\end{array}$ & 61 & $234.329 \pm 137.541$ & $237.412 \pm 122.079$ & 0.25 \\
\hline $\begin{array}{c}\text { Creatinine } \\
\text { (mg/dl) }\end{array}$ & 61 & $2.53 \pm 2.5$ & $2.23 \pm 2.28$ & 0.001 \\
\hline LDH (U/L) & 60 & $444.3 \pm 267.12$ & $316.22 \pm 124.06$ & 0.005 \\
\hline $\begin{array}{l}\text { Albumin } \\
\text { (g/dL) }\end{array}$ & 61 & $3.14 \pm 0.73$ & $3.10 \pm 0.65$ & 0.45 \\
\hline $\mathrm{Ca}(\mathrm{mg} / \mathrm{dL})$ & 61 & $8.83 \pm 0.71$ & $8.66 \pm 0.64$ & 0.10 \\
\hline $\mathrm{Na}(\mathrm{mEq} / \mathrm{L})$ & 59 & $136.86 \pm 4.63$ & $137.5 \pm 4.35$ & 0.08 \\
\hline $\mathrm{K}(\mathrm{mEq} / \mathrm{L})$ & 60 & $4.07 \pm 0.6$ & $4.10 \pm 0.62$ & 0.64 \\
\hline CRP (mg/dl) & 61 & $43.87 \pm 23.5$ & $21.17 \pm 12.1$ & 0.002 \\
\hline
\end{tabular}

LDH: lactate dehydrogenase, Ca: calcium, ALP: alkaline phosphatase, Na: sodium, K: potassium, CRP: C-reactive protein, SD: standard deviation, WBC: white blood cell, TPE: total plasma exchange
Table II: Laboratory changes after DFPP sessions

\begin{tabular}{|c|c|c|c|c|}
\hline & $\mathbf{n}$ & $\begin{array}{c}\text { Before DFPP } \\
\text { (Mean } \pm \text { SD) }\end{array}$ & $\begin{array}{c}\text { After } \\
\text { DFPP(Mean } \pm \text { SD) }\end{array}$ & $\mathbf{p}$ \\
\hline $\begin{array}{l}\text { Hemoglobin } \\
\text { (g/dl) }\end{array}$ & 76 & $10,7 \pm 2,2$ & $10,9 \pm 2$ & 0,341 \\
\hline $\begin{array}{c}\text { Hematocrit } \\
(\%)\end{array}$ & 76 & $31,9 \pm 7,1$ & $32,2 \pm 6,3$ & 0,675 \\
\hline $\begin{array}{c}\text { Platelets } \\
\left(10^{9} / \mathrm{L}\right)\end{array}$ & 75 & $267,2 \pm 125,1$ & $260,8 \pm 120,5$ & 0,642 \\
\hline $\begin{array}{c}\text { Creatinine } \\
\text { (mg/dl) }\end{array}$ & 77 & $2,26 \pm 2,3$ & $1,91 \pm 1,91$ & 0,094 \\
\hline LDH (U/L) & 44 & $373,7 \pm 363,4$ & $323,5 \pm 359,2$ & 0,459 \\
\hline $\mathrm{Na}(\mathrm{mEq} / \mathrm{L})$ & 75 & $136,6 \pm 4,9$ & $137 \pm 4,3$ & 0,580 \\
\hline $\mathrm{K}(\mathrm{mEq} / \mathrm{L})$ & 77 & $4,1 \pm 0,71$ & $4,3 \pm 0,61$ & 0,182 \\
\hline $\mathrm{Ca}(\mathrm{mg} / \mathrm{dL})$ & 76 & $8,9 \pm 0,64$ & $8,7 \pm 0,53$ & 0,004 \\
\hline CRP (mg/dl) & 69 & $42,4 \pm 47,5$ & $22,7 \pm 32,2$ & 0,003 \\
\hline $\begin{array}{l}\text { Albumin } \\
\text { (g/dL) }\end{array}$ & 69 & $3.12 \pm 0.73$ & $3.11 \pm 0.53$ & 0.35 \\
\hline
\end{tabular}

LDH: lactate dehydrogenase, Ca: calcium, ALP: alkaline phosphatase, $\mathrm{Na}$ : sodium, K: potassium, CRP: C-reactive protein, SD: standard deviation, WBC: white blood cell, DFPP: double filtration plasma

Complications [ cramps caused by hypocalcemia $(\mathrm{n}=9,7.4 \%)$, allergic reactions $(\mathrm{n}=6,5.40 \%)$, low blood pressure $(n=5,4.5 \%)$, fever $(n=4$, $3.4 \%$ ), deterioration in consciousness ( $\mathrm{n}=1$, $0.86 \%)$, low leucocytes $(n=1,0.86 \%)]$ were encountered in $26(22.4 \%)$ patients. No complications were encountered in $77.6 \%$ of the patients. Forty-four (37.3\%) cases had partial and 19 (16.1\%) had complete remission, and 46 (39\%) had no remission. $21.2 \%$ of the old patients died, and $13.4 \%$ of 97 adults became deceased because of the disease diagnosed. A positive correlation was found between age and mortality $(\mathrm{p}<0.001)$. No patient died because of the complications of DFPP or TPE. There was no difference between complication rates of DFPP and TPE $(\mathrm{p}=0.411)$. Of total 11\% (13) died within the first year of hospitalization with the diagnosed disease. Elderly patients $(\mathrm{p}<0.0001)$, the patients who need intensive care $(p=0.004)$, and the patients with autoimmune diseases $(\mathrm{p}=0.022)$ are more likely to die than the younger and the patients 
with neurological indications. $41 \%$ of the $15 \%$ remained on dialysis permanently. The patients needed dialysis at the beginning and clinical outcomes were summarized in Table 3.

Table III: Comparison of TDP and DFPP in clinical outcomes and complications

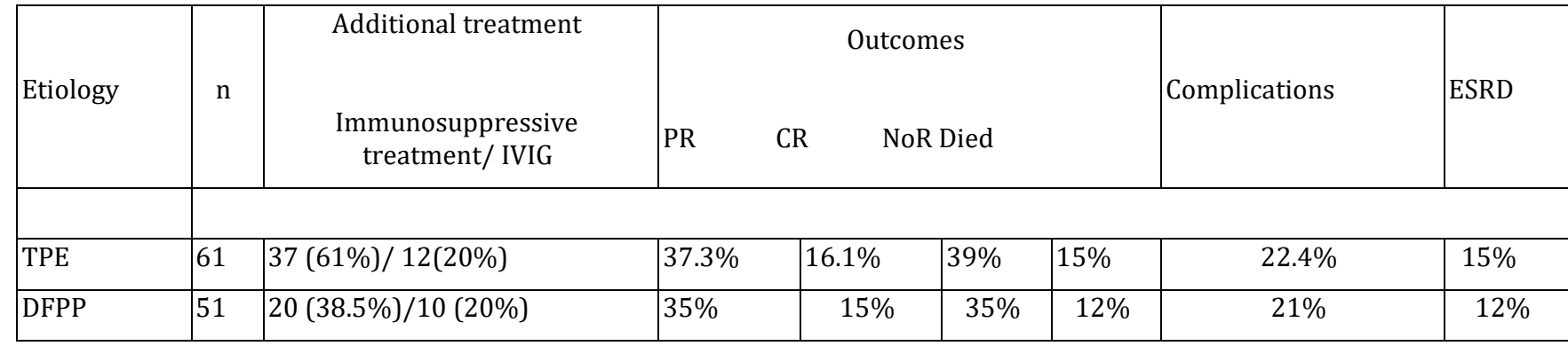

IVIG; intravenous immune globulin, ESRD; end-stage renal disease ;PR: partial response, CR: complete remission, NoR: no remission

\section{DISCUSSION}

TPE is a vital mode of treatment for diseases in which other therapies are not efficient to control the progress of the disease or provide remission. TPE has been performed with membrane separation technique with hemodiafiltration machine like a continuous dialysis procedure with only ultrafiltration mode and done in the hemodialysis unit in our hospital. Although tandem hemodialysis and TPE can be performed ${ }^{7}$, we preferred separate sessions when hemodialysis was also needed. There should be more studies to compare tandem with separate sessions for adults. The case series reporting plasma exchange therapies are mostly from intensive care units 8,9 , our experience was done in the nephrology hemodialysis unit. The mortality rate was found to be higher for the patients admitted from the intensive care unit although the overall mortality rate in our study was found lower than the ones reported previously most of which were done in intensive care units ${ }^{9}$. There should be larger case series comparing the efficiency and safety of the plasma exchange therapies between intensive care with hemodialysis units.

Plasma exchange discards the plasma from the disease-causing pathogens, fluid replacement is done with albumin or plasma in TPE. Cascade filtration reduces the loss of plasma and removes large components of the plasma more selectively like immune complexes and antibodies in DFPP. The plasma passes through the second filter with a smaller pore size which collects the smaller protein solutes like albumin and returns to the bloodstream. This method reduces the replacement blood products and the related complications. Double cascade filtration is mostly preferred in Japan and also less in Europe. This method was preferred in our center in almost half of the cases with enough experience and cases proved their efficiency and safety 4 . Complement system activation and hemolysis are more commonly seen in double cascade compared with single filtration and this was an important consideration for vulnerable diseases ${ }^{10}$ in our center but there were no significantly higher complications rates in the DFPP group compared with the single filtration technique. This method was more commonly used in autoimmune indications within neurological diseases ${ }^{11,12}$ and remission rates were higher in this group. Besides neurological indications, the total number of 55 patients underwent 391 sessions of DFPP in our center and this number is higher than the previous reports ${ }^{12}$. Compared with TPE, the patients in DFPP treatment sessions had a lower decrease in albumin levels like reported before ${ }^{1,13}$.

When the medical literature is examined, it is understood that the most common TPE is 
performed due to kidney diseases ${ }^{14}$. In our study, TPE has performed on adult patients mostly with renal-related (glomerulonephritis and HUS) conditions. Renal and neurologic diseases were the most frequent causes of DFPP treatment in adults.

Plasma exchange may reduce the progression of renal disease or death in renal vasculitis ${ }^{15}$. In our study, seventy-two (83.5\%) patients had partial and 2 (27.8\%) had full remission, and 20 (23.2\%) were non-responders. $14.7 \%$ died within the first year of hospitalization with the diagnosed disease.

TPE and DFPP are safe and vital membrane separation techniques used as a treatment for a wide spectrum of diseases. These treatments can be safely done in hemodialysis units intensive care units and DFPP should be considered for the therapy refractory neurological diseases.

Ethics Committee Approval: This study was accepted by University Ethical Committee with the document number KOU-GOKAEK-2019/328.

Declaration of Conflicting Interests: The authors declare that they have no conflict of interest.

Financial Disclosure: No financial support was received.

\section{REFERENCES}

1. Stegmayr B, Ramlow W, Balogun RA. Beyond Dialysis: Current and Emerging Blood Purification Techniques. Semin. Dial. 2012; 25: 207-13.

2. Williams M E, Balogun RA. Principles of separation: Indications and therapeutic targets for plasma exchange. Clinical Journal of the American Society of Nephrology 2014; 9: 181-90.

3. Padmanabhan A, Connely- Smith L, Aquio N, et al. Guidelines on the Use of Therapeutic Apheresis in Clinical Practice - Evidence-Based Approach from the Writing Committee of the American Society for Apheresis: The Eighth Special Issue. J. Clin. Apher. 2019; 34: 171-354.
4. Malchesky PS, Koo AP, Roberson GA, et al. Apheresis technologies and clinical applications: The 2005 International Apheresis Registry. Ther. Apher. Dial. 2007; 11: 341-62.

5. Alkhatib Y, Dadla A, Melik D., et al. Plasmapheresis and Myeloma Cast Nephropathy: A Meta-Analysis and Review of Evidence. Blood 2017; 130: 5415.

6. Li Q Y, Yu F, Zhou FD, et al. Plasmapheresis is associated with better renal outcomes in lupus nephritis patients with thrombotic microangiopathy a case series study. Med. 2016; 95: e3595.

7. Filler G, Clark WF, Huang SHS. Tandem hemodialysis and plasma exchange. Pediatr. Nephrol. 2014; 29: 2077-82.

8. Şeker YT, Hergünsel OG, Bilgi, DÖ. Therapeutic plasmapheresis: an eleven-year clinical experience. Eur. Res. J. 2018; 4: 343-48.

9. Yilmaz AA, Can OS, Oral M, et al. Therapeutic plasma exchange in an intensive care unit (ICU): A 10-year, single-center experience. Transfus. Apher. Sci. 2011; 45: 161-6.

10. Stegmayr B, Tärnvik A. Complement activation in plasma exchange by single filtration and centrifugation and in cascade filtration. Blood Purif. 1989; 7: 10-15.

11. Lyu RK, Chen W H, Hsieh S T. Plasma exchange versus double filtration plasmapheresis in the treatment of Guillain-Barré syndrome. Ther. Apher. 2002; 6: 163-6.

12. Hirano R, Namazuda K, Hirata N. Double filtration plasmapheresis: Review of current clinical applications. Therapeutic Apheresis and Dialysis.2021; 25: 145-51.

13. Maxted AP, Connell R, Hussain F. Double filtration plasmapheresis - 10-year pediatric experience as an alternative to plasma exchange. Transfus. Apher. Sci.2020; 59: 1029-8.

14. Clark WF. Plasma exchange for renal disease: Evidence and use 2011. in Journal of Clinical Apheresis 2012; 27: 112-6.

15. Walsh M , Catapano F, Szpirt W, et al. Plasma exchange for renal vasculitis and idiopathic rapidly progressive glomerulonephritis: A meta-analysis. Am. J. Kidney Dis.2011; 57: 566-74. 